\title{
The Roles and Responsibilities of Graduate Education Deans: Mapping Current and Future Job Challenges
}

\author{
John W. Murry \\ University of Arkansas \\ Michael T. Miller \\ University of Arkansas
}

Graduate education is changing, driven by social issues, expectations, and technology. Leaders of graduate education play important roles in understanding these changes. The purpose for conducting the study was to profile the professional setting of the graduate dean, exploring the roles, responsibilities, and challenges of the position. Using a research-team developed instrument, graduate education leaders were surveyed. Descriptive findings of the study included the nomenclature of titles who held full time appointments and had an academic background in the liberal arts. The roles and responsibilities of these respondents were reported as a group and separated by research and comprehensive universities.

Keywords: graduate education, college leaders, deans, administrators

\section{INTRODUCTION}

Graduate education is critically important to American higher education. These programs provide training and apprenticeships for future scholars and researchers, the preparation for higher education's faculty, and much of the professional preparation for varied careers ranging from law to health and education. And as these advanced academic programs, certificates, and credentials are relied upon to a greater extent than ever before, they are also being challenged as never before. Alternative academic terms, online and hybrid course delivery, newly automated processing and data information systems, electronic library and research support, etc. are all prominent issues in the current conversation about contemporary graduate education.

The response to challenges and opportunities facing graduate education is within the hands and control of the leaders of graduate study, typically a vice provost, dean, or director of graduate education, and for many institutions, with oversight for a unit termed a 'graduate school.' These roles typically evolved during times when institutions were primarily organized around undergraduate studies and specialized graduate work needed a different type and level of support. These graduate schools approved faculty to teach at the graduate level, admitted students and cleared them for graduation, and generally maintained curriculum and standards for graduate study within the academy.

The academy has evolved particularly quickly during the past half-century. Driven by advances in technology, a free-market based approach to public higher education, and changing professional standards, higher education has adopted a consumer-driven approach to meeting learner needs in many areas. For 
example, academic terms are no longer relegated to quarters or 16-week semesters, and mini-terms, 8-week terms, and intersession offerings have become common. Online learning has also become common, and graduate programs that once could claim a particular geographic region of service must now compete with institutions in distant locations. One of the primary results of this evolution is that the idea of graduate education is changing, and how it is structured and delivered is as well.

The purpose for conducting the study was to profile the professional setting of the graduate dean position in American higher education. Specifically, the study sought to identify the roles, responsibilities, and challenges of the graduate dean position.

\section{BACKGROUND OF THE STUDY}

When looking at the current state of graduate education, it is important to review the history and how it has influenced the present situation. The first master's degree in the United States was awarded in 1642 at Harvard University (Harriman, 1938). Based on the medieval universities of Europe, a master's degree was conferred after three years post baccalaureate, examination, and a payment of fees. There was no specific curriculum or course requirements, the only requirement being the length of time spent in study. The idea was that students would obtain something, an advanced degree, if they put in enough time at an institution. In 1861, Yale was the first institution in the United States to award the Doctor of Philosophy (Ph.D.) degree (Thelin, 2001). With little regulation, most advanced degrees were offered by institutions with little regard to academic rigor, and degrees were given by submitting a fee. Any sort of supervised research was rare, and little in the way of assessment was typically required (Thelin, 2001).

Following the beginning of doctoral programs in the US, the higher education community began to express more interest in standards for degrees at both the undergraduate and graduate level in the 1860's. Some of the recommendations concerning advanced education were that courses had to be at the graduate level and actually differentiated from undergraduate courses, examinations should be given to assess proficiency, and the use of an original written thesis (Harriman, 1938). These trends and dialogues in graduate education were the beginning of a significant shift in higher education generally, and the founding of Johns Hopkins in 1876 was a clear demonstration of this shift. "It was the most impressive example of the German university's ideals of advanced scholarship and Ph.D. programs being transplanted to the United States" (Thelin, 2001, p. 90). In this model, advanced scholarly work was based on concentrated interest in a subject and laboratory research. For the first time, clear standards were being created for graduate degrees, and individuals were being hired to direct the implementation of these standards.

From the late-1800s through the early-1900s, the evolution of graduate education was seen in the broad variation of the quality of graduate study being offered. Some degrees were offered by degree 'mills,' while others were based on the rising notion of the German ideas about graduate research. According to Thelin (2001), during this time, over about a 15 year period, about two hundred doctoral degrees were awarded.

Around this same time, administration began to arise as a profession on college campuses. The first deans were 'deans of women.' Between 1890 and 1930, women were just starting to make a larger appearance on college campuses. During the Victorian era, parents wanted to make sure that their daughters were sufficiently protected and kept separate from male students (Schwartz, 1997). Deans of women more often than not had trained to become faculty, but found themselves in the position of protecting and guiding female students. The first official title of 'dean of men' was given to Thomas Arkle Clark at the University of Illinois in 1909 (Schwartz, 1997). The dean of women position lost some of its importance after World War II because Victorian ideals lost most of their hold over the younger population.

Throughout the $20^{\text {th }}$ century, a number of administrative and professional positions have arisen on the college campus. Beginning with a surge in hiring individuals to process enrollment growth post-World War II, administration on college campuses has grown to respond to various needs, including changing student engagement, different types of computing requirements, fundraising, fiscal management, and recently, information systems management.

Emerging initially in the early-1900s and then expanding with the research-intensive Cold War investment, graduate education and research evolved together, often with the creation of unique units called 
'graduate schools.' Concurrently, the leader of these units similarly grew, often resulting in the position of 'graduate dean.'

One of the roles of the graduate dean is to document the quality and effectiveness of graduate programs. According to Shabb (2004), graduate deans do not have faculty members who report directly to them and some do not have a direct budget to improve graduate education, which means that they do not have the traditional authority that some academic deans have to achieve their program objectives. Graduate deans have sometimes been charged with the growth of nontraditional programs, interdisciplinary centers, graduate recruitment, as well as being involved with fundraising (Hoving, Woodruff, \& Musacchia, 1989). The trend has been for graduate deans to be more involved with graduate research and the outside funding, than with graduate students and faculty.

The study conducted by Shabb (2004) specifically looked at the roles of deans in graduate education. The most frequently mentioned issues reported by the graduate deans were petitions, policies, and program development. The majority of the graduate deans had the final say on graduate school petitions, that is, exceptions to certain rules. These petitions came from students and faculty, and frequently centered around admissions requirements, grade changes, leaves of absence, late course withdrawal, candidacy petitions, and degree extensions. The petitions from faculty focused on exceptions to policies and standards. According to this study, another role of the graduate dean is to uphold the standards of graduate education. This is often done by supervising the institution's policies by acting as an ombudsperson, developing graduate programs, and protecting the students. The author defined the ombudsperson as someone who reviews and tries to resolve issues as well as explaining the policies to others (Shabb, 2004). Some of the policies that a graduate dean oversees are related to graduate admissions, assistantships, or graduation requirements. Similarly, the graduate dean is responsible for implementing the policies (Block, 2008). Specifically, the graduate dean is involved with creating the policies with faculty members, implementing them, and tracking to maintain the quality of the graduate school. The graduate deans in the study conducted by Shabb, stated that it took approximately three to seven years for a new program to be developed (2004). The dean's role in new program development revolves around facilitating the approval process and encouraging the faculty to come up with new programs. The deans in this study suggested that they felt successful when new programs were developed and approved. According to this study, the graduate dean is most responsible for creating and maintaining a high standard of academic excellence at their institution.

The graduate deans' involvement with faculty members can vary greatly. One article stated that some graduate deans review tenure decisions and promotion, but most are not responsible for hiring, mentoring, or reviewing faculty members (Cohen, 2007). In addition, this author stated that graduate deans do not supervise nor are they directly responsible for students at their institution. This author also suggested that graduate deans are responsible for supervising the academics and administration of graduate programs, but have no budgetary authority for them. The most common factor that this author found among graduate deans was their commitment to progressing graduate education at their institution. One study found that graduate deans' position on campus may influence doctoral completion through their ability to affect policies (Elgar \& Klein, 2004). According to these authors, the role of the graduate dean was to advise schools and faculty on program requirements, thesis guidelines, supervision of students, and thesis examinations. In addition, their role as a leader on campus can impact parts of student life such as handling student grievances, finding funding for assistantships, and other campus services available to students (Elgar \& Klein, 2004). Supporting what has been stated so far, one study found that graduate deans had the most responsibility for creating policies, reviewing programs, and recommendations regarding program termination (Lawrence, 1984).

\section{RESEARCH METHODS}

The population of the study was comprised of all doctoral institutions, both public and private, listed in the 2018 Carnegie Classification of Institutions of Higher Education as R1, Very High Research Activity. This included 131 universities. Also included were doctoral institutions listed as R2 High Research Activities ( $\mathrm{n}=135$ universities), resulting in the identification of 266 institutions. These institutions were 
then reviewed online to identify the senior graduate education officer, typically a dean of a graduate school but also referred to as a vice provost or vice chancellor for graduate education.

The study made use of a research-team developed survey instrument. The first section of the survey contained descriptive questions about the senior graduate officer's role including title and the background (demographic information) of the individual completing the survey. The second section of the survey included the rating of 14 different roles for the position and then rating the importance of 10 different responsibilities of the role. The third section of the survey included 12 different challenges for the graduate education leaders position. Data for the second and third sections of the survey were drawn from the literature on academic leadership broadly, as well as reports of current concerns for graduate education.

Upon the survey's initial construction, it was administered to a non-participant sample of 25 academic leaders working in graduate education. These reviewers offered comments and wording changes to clarify the instrument's wording and structure. Following the revisions to the survey, it was administered to the sample in the spring of 2021.

\section{FINDINGS}

Of the 227 names and email addresses included in the initial sample, 11 were returned for various reasons, including that the individual identified no longer was employed at the institution. Of the remaining 216 possible senior graduate education professionals, 64 responded to all or part of the survey (29.62\%), and of those 64,56 were fully completed and deemed usable in the study analysis $(25.9 \%$ usable response rate). The majority of respondents represented comprehensive universities $(n=32 ; 56.1 \%)$, did not have responsibilities for research administration $(n=49 ; 87.5 \%)$, and over $80 \%$ of the respondents indicated that their campus' graduate enrollment was between 501-2000 students (see Table 1).

TABLE 1

\section{CHARACTERISTICS OF RESPONDENTS}

\begin{tabular}{|l|l|l|}
\hline Variable & $n$ & $\%$ \\
\hline University Classification & & \\
\hline Research Focused & 23 & 40.4 \\
\hline Comprehensive & 32 & 56.1 \\
\hline Professional & 2 & 3.5 \\
\hline Undergraduate Focused & 0 & 0 \\
\hline & & \\
\hline Current graduate enrollment & & \\
\hline Under 500 & 8 & 14 \\
\hline $501-1,000$ & 23 & 40.4 \\
\hline $1,001-2,000$ & 24 & 42.1 \\
\hline More than 2,000 & 2 & 3.5 \\
\hline & & \\
\hline Research Administration & & \\
\hline Part of administrative unit & 7 & 12.5 \\
\hline Not part of unit & 49 & 87.5 \\
\hline
\end{tabular}

\section{Who Runs Graduate Programs?}

The first section of the survey sought to profile the responding graduate school or programs leaders. As shown in Table 2, three-fourths of these individuals held the title "dean" ( $\mathrm{n}=43,75.4 \%)$, held the role as a full-time appointment $(\mathrm{n}=51 ; 89.5 \%)$, and came from faculty appointments in a variety of academic disciplines, notably the sciences $(n=14 ; 24.6 \%)$, the liberal arts and humanities $(n=13 ; 22.8 \%)$, and education $(\mathrm{n}=12 ; 21.1 \%)$. The majority of the responding graduate leaders had been in their roles under 10 
years $(\mathrm{n}=50 ; 83.1 \%)$, were evenly divided between cis-gender male $(\mathrm{n}=28 ; 49.1 \%)$ and cis- gender female $(\mathrm{n}=29 ; 50.9 \%)$, and nearly half were over the age of $55(\mathrm{n}=28 ; 49.1 \%)$. And, only a third of the responding graduate leaders indicated an intent to remain in their current role during the next five years, with a quarter of respondents uncertain about their plans $(\mathrm{n}=14 ; 24.6 \%)$.

TABLE 2

CHARACTERISTICS OF GRADUATE LEADERS

\begin{tabular}{|c|c|c|}
\hline Variable & $n$ & $\%$ \\
\hline \multicolumn{3}{|l|}{ Title } \\
\hline Dean & 43 & 75.4 \\
\hline Vice Provost & 8 & 14 \\
\hline Director & 6 & 10.5 \\
\hline \multicolumn{3}{|l|}{ Length in the role } \\
\hline Under 5 years & 26 & 45.6 \\
\hline $6-10$ years & 24 & 37.5 \\
\hline More than 10 years & 7 & 12.3 \\
\hline \multicolumn{3}{|l|}{ Personal Academic Background } \\
\hline Liberal Arts/Humanities/Fine Arts & 13 & 22.8 \\
\hline Sciences & 14 & 24.6 \\
\hline Nursing/Allied Health & 5 & 8.8 \\
\hline Business Administration & 5 & 8.8 \\
\hline Engineering & 5 & 8.8 \\
\hline Education/Human Sciences & 12 & 21.1 \\
\hline Agriculture/Natural Sciences & 2 & 3.5 \\
\hline Architecture & 1 & 1.8 \\
\hline \multicolumn{3}{|l|}{ Appointment } \\
\hline Full-time position & 51 & 89.5 \\
\hline Release from faculty role & 6 & 10.5 \\
\hline \multicolumn{3}{|l|}{ Gender } \\
\hline Cis-gender Male & 28 & 49.1 \\
\hline Cis-gender Female & 29 & 50.9 \\
\hline \multicolumn{3}{|l|}{ Current age range } \\
\hline Under 30 & 0 & 0 \\
\hline $30-44$ & 11 & 19.3 \\
\hline $45-54$ & 18 & 31.6 \\
\hline $55-64$ & 23 & 40.4 \\
\hline 65 and over & 5 & 8.8 \\
\hline \multicolumn{3}{|l|}{ Plans for the next 5 years } \\
\hline Stay in same position & 19 & 33.3 \\
\hline Move to similar position at a different institution & 5 & 8.8 \\
\hline Return to faculty role & 10 & 17.5 \\
\hline Uncertain & 14 & 24.6 \\
\hline
\end{tabular}




\section{Roles}

Responding graduate leaders were asked to rate their agreement with a series of professional roles that have been attributed to academic leadership in general. They agreed most strongly that their roles as graduate program leaders were Advocator $(\bar{x}=4.84$; SD .368), Planner ( $\bar{x}=4.81$; SD .398), Information disseminator $(\bar{x}=4.79$; SD .411) Conflict resolver $(\bar{x}=4.70 ; .533)$. The roles that these respondents least agreed that they held included Delegator $(\bar{x}=3.86$; SD 1.008), Mentor $(\bar{x}=3.68$; SD .783), and resource allocator $(\bar{x}=3.58$; SD 1.017) (see Table 3 ).

TABLE 3

PERCEPTIONS OF ROLE

\begin{tabular}{|l|l|l|l|}
\hline Role & Mean & SD & Range \\
\hline Advocator & 4.84 & .368 & 1 \\
\hline Planner & 4.81 & .398 & 1 \\
\hline Information disseminator & 4.79 & .411 & 1 \\
\hline Conflict resolver & 4.70 & .533 & 2 \\
\hline Facilitator & 4.60 & .563 & 2 \\
\hline Motivator & 4.53 & .758 & 4 \\
\hline Negotiator & 4.47 & .658 & 3 \\
\hline Evaluator & 4.44 & .682 & 3 \\
\hline Entrepreneur & 4.28 & .620 & 3 \\
\hline Visionary & 4.19 & .895 & 4 \\
\hline Caretaker & 4.16 & .882 & 4 \\
\hline Delegator & 3.86 & 1.008 & 4 \\
\hline Mentor & 3.68 & .783 & 4 \\
\hline Resource Allocator & 3.58 & 1.107 & 4 \\
\hline
\end{tabular}

\section{Responsibilities}

As shown in Table 4, responding graduate leaders were asked to rate their agreement about the importance of several responsibilities related to graduate education. Responding graduate leaders agreed most strongly that their responsibility was for student recruitment $(\bar{x}=4.95$; SD .225), followed by oversight of graduate degree programs $(\bar{x}=4.91 ; .288)$, oversight of the graduate curriculum $(\bar{x}=4.84 ;$ SD .414$)$ and managing student records $(\bar{x}=4.77$; SD 535). These responding professionals agreed least with the responsibilities of overseeing graduate faculty $(\bar{x}=3.74$; SD .856) and overseeing research activities $(\bar{x}$ $=3.05 ; 1.315$ ). To better understand how these responsibilities might vary among institutional types, responses were sorted into the categories of 'research university respondents' and 'comprehensive university respondents.' Although there were differences in the agreement levels for each responsibility identified, there were only two significant differences identified. Research university graduate leaders agreed significantly more strongly that their responsibility was for the professional development of graduate students ( $p>$.05; Sig. .027) and that they had significantly more of a responsibility for the oversight of research activities (p..05; .006). 
TABLE 4

IMPORTANCE OF RESPONSIBILITIES

\begin{tabular}{|l|l|l|l|l|l|}
\hline Responsibility & RU & CU & Mean & SD & Range \\
\hline Student recruitment & 4.91 & 4.97 & 4.95 & .225 & 1 \\
\hline Oversight of degree programs & 4.87 & 4.94 & 4.91 & .288 & 1 \\
\hline Oversight of graduate curriculum & 4.83 & 4.91 & 4.84 & .414 & 2 \\
\hline Management of student records & 4.78 & 4.84 & 4.77 & .535 & 3 \\
\hline $\begin{array}{l}\text { Professional development for } \\
\text { graduate students }\end{array}$ & 4.74 & 4.59 & $4.61^{1}$ & .526 & 2 \\
\hline Student retention & 4.50 & 4.48 & 4.40 & .873 & 3 \\
\hline Assuring program compliance & 4.61 & 4.25 & 4.35 & .694 & 3 \\
\hline Assuring student compliance & 4.57 & 4.19 & 4.32 & .711 & 3 \\
\hline Oversight of graduate faculty & 4.09 & 3.59 & 3.74 & .856 & 4 \\
\hline Oversight of research activities & 3.39 & 2.88 & $3.05^{2}$ & 1.315 & 4 \\
\hline
\end{tabular}

1 Sig .027; 2 Sig .006

\section{Importance of Oversight}

The last section of the survey asked responding graduate leaders to rate the importance they perceived with several critical issues facing graduate education, as identified in the popular and academic literature. As an overall group, they agreed most strongly that the most important area of oversight that they had was for student recruitment $(\bar{x}=5.00$; SD. .000), followed by COVID recovery $(\bar{x}=4.96$; SD. 187$)$, and technology use in record/system management $(\bar{x}=4.56$; SD. 501). They agreed least with the issues of competition with proprietary institutions $(\bar{x}=2.62$; SD 1.613), eliminating graduate schools $(\bar{x}=2.39$; SD. 1.532), and graduate student collective bargaining $(\bar{x}=1.93$; SD 1.498). Again, to understand better these areas of oversight, data were separated into responses received from research universities and comprehensive universities (see Table 5). The mean ratings were largely consistent between the two groups, with the exception of research university respondents agreeing more that student retention was an area to be concerned with while comprehensive university respondents agreed significantly less (RU $\bar{x}=4.64$; $\mathrm{CU}$ $\bar{x}=3.38 ; \mathrm{p}>.05$, Sig. .009). Two other areas of oversight differed significantly between the two groups of respondents, including competition with online programs (Sig. .030) and graduate student collective bargaining (Sig. 001).

TABLE 5

IMPORTANCE OF GRADUATE EDUCATION OVERSIGHT

\begin{tabular}{|l|l|l|l|l|l|}
\hline Area of oversight & RU & CU & Mean & SD & Range \\
\hline Student recruitment & 5.0 & 5.0 & 5.0 & .000 & 0 \\
\hline COVID recovery & 4.91 & 5.0 & 4.96 & .187 & 1 \\
\hline $\begin{array}{l}\text { Technology use in } \\
\text { record/system } \\
\text { management }\end{array}$ & 4.61 & 4.53 & 4.56 & .501 & 1 \\
\hline $\begin{array}{l}\text { Graduate assistant } \\
\text { compensation }\end{array}$ & 4.57 & 4.50 & 4.47 & .170 & 4 \\
\hline Student retention & 4.64 & 3.38 & $4.45^{1}$ & .737 & 3 \\
\hline $\begin{array}{l}\text { International student } \\
\text { enrollment }\end{array}$ & 4.30 & 4.31 & 4.32 & .909 & 3 \\
\hline $\begin{array}{l}\text { Technology use in } \\
\text { research }\end{array}$ & 3.96 & 4.13 & 4.02 & .551 & 3 \\
\hline
\end{tabular}




\begin{tabular}{|l|l|l|l|l|l|}
\hline $\begin{array}{l}\text { Competition with online } \\
\text { programs }\end{array}$ & 3.55 & 4.06 & $3.88^{2}$ & 1.502 & 4 \\
\hline $\begin{array}{l}\text { Competition with } \\
\text { proprietary institutions }\end{array}$ & 2.26 & 2.81 & 2.62 & 1.613 & 4 \\
\hline $\begin{array}{l}\text { Reorganization/elimination } \\
\text { of graduate schools }\end{array}$ & 2.74 & 2.22 & 2.39 & 1.532 & 4 \\
\hline $\begin{array}{l}\text { Graduate student collective } \\
\text { bargaining }\end{array}$ & 2.78 & 1.38 & $1.93^{3}$ & 1.498 & 4 \\
\hline
\end{tabular}

1Sig .009; 2Sig .030; 3Sig .001

\section{DISCUSSION}

The findings of the current study are limited in two significant ways. First, the response rate was relatively good for an online survey, but was somewhat low. An association such as the Council on Graduate Schools might have more success in garnering a higher response rate, that this is important simply to help determine what the current and future demand for graduate education leaders is and might be. Second, though, the difference in responses from the research universities and comprehensive universities might be worth considering further. Comprehensive institutions might, for example, have less of a residential graduate education component, and that in turn might dictate the roles, responsibilities, and outlook for graduate education leaders. Similarly, there seems to be a number of institutions (about 10\%) that continue to include research administration with their graduate education unit, and this model could be explored and expanded to identify the strengths, weaknesses, and unique challenges of such a structure.

In terms of respondents, the title 'dean' was the most common, and academic backgrounds and time in the position were fairly evenly distributed. Nearly all respondents indicated that their role was a full-time position, as opposed to a release-time assignment from a faculty role, and there was a very even distribution based on gender. And although there was a broad range of ages represented in the role, two-thirds of respondents indicated that they were either uncertain or were planning to leave the role within the next five years. This would suggest a somewhat mobile graduate professional workforce, and could also be a signal that there is a strong future demand for individuals to move into these roles.

The agreement on the roles of the graduate leader position were consistent with general thinking about what these leaders undertake. They advocate for programs and students, plan programs and curriculum, share information on deadlines and rules and regulations, and resolve conflict between students and faculty. Similarly, there was the least agreement with the role of allocating resources, which suggests that graduate education units facilitate program offerings rather than control their purse strings. This may, also, differ based on institutions that have research administration, and the indirect costs associated with these activities, at their discretion to allocate.

The importance of job responsibilities highlighted the strong need for graduate education programs to be at the forefront of student recruitment. These units also have a strong, highly agreed upon responsibility for overseeing graduate programs and curriculum while maintaining student records. The lower level of agreement for oversight of the graduate faculty does illustrate the unique relationship that graduate schools in particular have with the idea of graduate faculty. Most graduate schools have criteria and formal approval process for granting graduate faculty status (to teach, serve on committees, mentor students, etc.), yet once they are approved, there might be little in the way of overseeing their activities, relegating such responsibility to the academic homes of these faculty.

And finally, in terms of importance, the most agreed upon area of oversight included student recruitment, the obvious importance of recovering from the Covid pandemic, and using technology in record and system management. The legacy procedures of faculty signing physical, paper forms, seems to be giving way to automated signature and approval protocols, and for some institutions this may be a difficult change.

Overall, these findings seem to stress that a major role for graduate education deans and leaders is student recruitment. Although not differentiated in the current study, an implied role in diverse student 
recruitment would seem logical. This means that successful graduate leaders have a strong understanding of marketing principles, the role of electronic messaging to encourage enrollment, and a sensitivity to student needs. These students needs further need to be differentiated between the rapid growth of online program offering coupled with the highly residential, research-intensive kinds of graduate experiences that are a hallmark of disciplines such as the hard sciences. Continued, further study about the role and future of graduate education and its needed leadership will help to assure that graduate education continues to play a significant role in American higher education.

\section{REFERENCES}

Block, B.A. (2008). Navigating the swamp of graduate education: A principles, policies, and procedures in Kinesiology perspective. The Chronicle of Kinesiology and Physical Education in Higher Education, 19(1), 16-17.

Cohen, P. (2007). The graduate dean as Pope? Academe, 93(3), 45-48.

Elgar, F.J., \& Klein, R.M. (2004). What you don't know: Graduate deans' knowledge of doctoral completion rates. Higher Education Policy, 17(3), 325-336.

Harriman, P.L. (1938). The master's degree. The Journal of Higher Education, 9(1), 23-38.

Hoving, K.L., Woodruff, G., \& Musacchia, X.J. (1989). The changing role of the graduate dean. Communicator, 22(8-9).

Lawrence, J.V. (1984). A study of the graduate deanship: Does gender make a difference? Washington, DC: Council of Graduate Schools.

Schwartz, R.A. (1997). How deans of women became men. Review of Higher Education, 20(4), 419-436. Retrieved from http://0-search.proquest.com.library.uark.edu/docview/62608880?accountid=8361

Shabb, C.H. (2004). The graduate dean as guardian of standards and academic excellence. Available from ProQuest Dissertations \& Theses Global: Social Sciences (305166907).

Thelin, J.R. (2011). A history of American higher education (2nd ed.). Baltimore, MD: The Johns Hopkins University Press. 